MUZIKOLOŠKI ZBORNIK - MUSICOLOGICAL ANNUAL IX, LJUBLJANA 1973

UDK 784.4 (438) Beethoven

\title{
POLJSKE LJUDSKE PESMI V PRIREDBI LUDWIGA VAN BEETHOVNA
}

\author{
Zofia Lis s a (Warszawa)
}

Na meji med 18. in 19. stoletjem je meščanstvo zahodne Evrope doseglo višjo kulturno raven in začutilo potrebo po mnogih glasbenih zvrsteh, ki v preteklih stoletjih - v drugačnem družbenem redu - niso imele večje vloge $\mathrm{v}$ glasbenem življenju. Čeprav ne spadajo vselej v zgodovino t.i. »velike muzike«, imajo danes, v skladu $\mathrm{s}$ težnjo po razrednem pogledu na razvoj glasbene kulture, $\mathrm{v}$ nekaterih priročnikih za glasbeno zgodovino ${ }^{1}$ že svojo polno in pravilno oceno. Ena takih zvrsti na prelomu 18. in 19. stoletja so priredbe ljudskih pesmi raznih evropskih narodov - poleg salonskih oblik plesne ali lirske miniature, ustrezajočih možnostim sprejemanja in izvajanja v krogih, ki so tedaj prihajali na oblast. Na rast pomena folklornih obdelav so vplivala ne le osvobodilna gibanja mnogih narodov srednje Evrope, temveč so to rast pripravile tudi še starejše misli nemškega filozofa J.G. Herderja, ki je že v 18. stoletju prvič izoblikoval tezo o izrednih vrednotah folklore raznih narodov in o njenem tehtnem pomenu za posamezne narodne kulture. ${ }^{2} \mathrm{Z}$ dejanjem je podkrepil ta svoj nazor, ko je v letih 1778/79 izdal zbirko pesmi raznih narodov kot "Stimmen der Völker in Liedern «. ${ }^{3}$

$\mathrm{Na}$ prelomu 18. in 19. stoletja so se s prirejanjem številnih ljudskih pesmi ob spremljavi klavirja ali instrumentalnih ansamblov ukvarjali že J. Haydn, J. A. Koželuch, J. N. Hummel, I. Pleyel in še veliko drugih pomembnih skladateljev. Poleg drugih se je za to zvrst zanimal - in to že precej zgodaj, v glavnem pa od leta 1810 - tudi Ludwig van Beethoven. Njegove priredbe škotskih, irskih in wale-

${ }^{1}$ G. Knepler, Die Musik des XIX. Jahrhunderts. Berlin, 1962, zv. II, pogl. IV, str. 484 in sl.

2 J.G. Herder, Ideen zur einer Philosophie der Geschichte der Menschheit, 1784-1791, 3 zv.; zbirka: 1877-1913, XIV.zv., str. 77 idr.

3 J. G. Herder, Volkslieder, 1778-1779; druga izdaja "Stimmen der Völker«, 1807 (ured. J. Müller); zadnja izdaja 1954. 
ških pesmi so splošno znane; posvetili so jim celó vrsto študij. ${ }^{4}$ Do nedavna pa sploh niso vedeli, da je Beethoven med svojimi približno 200 priredbami ljudskih pesmi ${ }^{5}$ priredil v letih 1816/18 tudi 24 pesmi raznih evropskih narodov in jih združil v zbirko $\mathrm{z}$ naslovom »Chants des diverses nations « ter da je $\mathrm{v}$ tej zbirki tudi vrsta slovanskih pesmi: 2 poljski, 4 ruske in 1 ukrajinska.

$\mathrm{V}$ tem članku bi si radi ogledali prav priredbi polj s kih pesmi. Res predstavljata ti dve pesmi v primerjavi z veliko količino priredb škotskih, irskih in waleških ter nemških in avstrijskih pesmi le neznatno število, vendar pričata po eni strani o mnogovrstnem Beethovnovem zanimanju za folkloristiko, po drugi strani pa vsaj od daleč odsevata tisti interes za "goût polonais«, za plese alla polacca, tj. za poloneze, ki se je razvil v 18. stoletju zlasti v Nemčiji. Sledove te razsvetljenske tradicije najdemo namreč tudi $\mathrm{v}$ Beethovnovi ustvarjalnosti, v obliki 7 polonez, o katerih bo še govora.

Da bi pokazali, kako zelo so se zanimali že nemški skladatelji 18. stoletja za zvrst poloneze in celo za poljsko folkloro, bo dovolj, če navedemo nekaj izjav tedanjih teoretikov in komponistov. J. Mattheson ${ }^{6}$ pravi: $\gg D i e$ polnische Art des choräischen Stils hat seit einiger Zeit so viel Beyfall gefunden, dass man sich nicht scheuet die ernsthaftesten Worte und Empfindungen... mit Melodien nach Polnischer Weise, à 1 a polon a i s e, zu versehen..... J. Scheibe piše kar o "poljskem stilu v nemški glasbi«, ${ }^{7}$ a F. W. Marpurg se celo razburja, da »poljski stil« premočno vpliva na nemško glasbo. ${ }^{8}$ Vredno je navesti še izjavo G. Ph. Telemanna, ki je ugotavljal, da je poljska folklora tako bogata in raznorodna, da lahko nudi skladatelju tematsko gradivo za vse življenje: „... man sollte kaum glauben was dergleichen Bockpfeiffer oder Geiger für wundervolle Einfälle haben, so oft die Tanzenden ruhen...». »Ein Aufmerksamer könnte von diesen in acht Tagen Gedanken für ein ganzes Leben erschnappen...»»...ich selbst habe... verschiedene grosse Concerti und Trii in deren Art geschrieben, die ich in einen italienischen Rock... eingekleidet... habe«. Telemann je zapisal te stavke v svoji avtobiografiji, ki jo je J.Mattheson uvrstil v »Grundlage der Ehrenpforte»

${ }^{4}$ C. Hopkins and B. C. Oldman, Thomson's Collection of National Songs, with Special Reference to the Contribution of Haydn and Beethoven, v: »The Edinburgh Bibliographical Society....., II. zv., I. del, Edinburgh, 1940; H. Boetticher: Beethoven als Liederkomponist, Augsburg, 1928, idr.

${ }_{5}$ Po računih Kinskyja (G. Kinsky und H. Halm, Thematisch - Bibliographisches Verzeichniss aller vollendeten Werke Ludwig van Beethovens, München-Duisburg, 1955) je Beethoven priredil 152 škotskih, waleških in irskih pesmi, poleg tega več deset nemških, avstrijskih, tirolskih, švedskih, italijanskih pesmi in ljudske pesmi drugih evropskih narodov, med temi štiri ruske, eno ukrajinsko in dve poljski, pri tem pa ni upošteval skic za priredbe te vrste.

6 J. Mattheson, Kern melodischer Wissenschaft, Leipzig, 1737.

7 J. Scheibe, Compendium musices theoretico-practicum, Leipzig, 1730.

$\checkmark$ F. W. Marpurg, Des kritischen Musicus an der Spree erster Band, Berlin, 1750. 
leta $1740 .^{9}$ Slednjič navedimo še izjavo nemškega estetika s konca 18. stoletja Chr. Fr. D. Schubartha, ${ }^{10}$ ki priča o tem, da so bile še v Beethovnovem času poljske ljudske pesmi precej splošno znane in da so jim priznavali posebno lepoto: "Die Volksmelodien dieser Nation sind so majestätisch, dabei aber so niedlich, dass sie in ganz Europa nachgeahmt werden. Deren Lieder und Tänze gehören zu den schönsten und anziehendsten von denen aller anderen Völker ... Sogar die allgemeine Not und Leid, welche diese Nation im Vergleich $\mathrm{zu}$ allen anderen zu tragen hatte, konnte den Geist ihrer Musik nicht vernichten... Ta izjava med drugim dokazuje, da je Schubarth dobro vedel za usodo podjarmljenega poljskega naroda.

Vendar se je v 18. stoletju zanimanje nemških skladateljev osredotočilo $\mathrm{v}$ glavnem na poloneze (Kirnberger, J.S. Bach, Händel in sinovi J. S. Bacha - Wilhelm, Friedemann in Karl Philipp Emanuel, Telemann, Schobert in drugi), in njihova tradicija je bila še proti koncu stoletja dovolj močna, da je mogla vplivati na Beethovna. $\mathrm{V}$ začetku 19. stoletja pa narašča bolj vsestranski interes za ljudsko glasbo raznih narodov; ta interes je bil že pri predromantikih intenziven in je moral postati dodatna spodbuda za Beethovna. Nič ni torej čudnega, da je Beethoven, ko se je na iniciativo svojega edinburškega založnika $\mathrm{G}$. Thomsona ${ }^{11}$ lotil prirejanja zbirke ,kontinentalnih pesmi" z naslovom "Chants des diverses nations «, vključil vanjo poleg nemških, tirolskih, italijanskih, švedskih, ruskih in drugih pesmi tudi dve poljski. Gradivo za to zbirko je skladatelj našel $\mathrm{v}$ raznih pesmaricah in notnih prilogah $\mathrm{h}$ glasbenim revijam; ruske je vzel iz zbirk I. Pracza in I. Trutowskega, ki sta mu jih poslala njegova ruska mecena grof Razumovski in knez Golicyn. ${ }^{12}$ To pa, kje je našel vir za poljske melodije, je bilo zame dolgo let nerazrešljiv problem. Tiskanih zbirk poljske folklore pred letom 1816 še ni bilo, Beethovnovi stiki s poljskimi glasbeniki, ki so živeli na Dunaju, pa so bili bolj slabi in kratkotrajni. Na Poljskem Beethoven nikoli ni bil, čeprav ga je leta 1799 povabil tja neki neznan in vse doslej neugotovljen prijatelj ali kolega. $O$ tem poroča sam v pismu konec poletja 1799 (avgusta ali v začetku septembra - pismo ni datirano): da je dobil tako povabilo, da ga je sprejel in da namerava odpotovati na Poljsko, ker bo lahko tam imel brezplačno

9 J. Mattheson, »Grundlage der Ehrenpforte«, Leipzig, 1740.

${ }^{10}$ Chr. Fr. D. Schubarth, Ideen zur einer Aesthetik der Tonkunst, Wien, 1806 , str. 248/9.

11 R. Aldrich, Beethoven and George Thomson, v: "Music and Letters", London, 1927, letnik VIII, snopič 4, str. 242.

12 Z grofovsko družino Razumovski je Beethoven ostal v stikih zaradi tega, ker je bil eden od njih oženjen s sestro skladateljevega dunajskega mecena kneza Lichnowskega. Sloveči kvarteti "Razumovskega" op. 59 uporabljajo prav motive ruskih pesmi iz skladatelju poslanih zbirk: I. Pracz (in N. Lwow): Sobranije ruskih narodnyh pesenj $\mathrm{s}$ ih golosami. Petersburg, 1790, 2. izd. 1806, 3. izd. 1815. Zbirka W. F. Trutowskega izvira iz let 1776-1795: Sobranije ruskih prostyh pesenj $\mathrm{z}$ notami, Petersburg, snopič 1-4. Stiki s knezom Golicynom - subskribentom Beethovnove "Missae solemnis« segajo prav tako v prejšnja leta. 
oskrbo, se malo pozabaval in tudi... zaslužil nekaj denarja, Pismo je poslal svojemu estonskemu prijatelju pastorju Karlu Amendu. ${ }^{13}$

Ko sem v letih 1967/69 pripravljala za Poljsko glasbeno založbo (Polskie Wydawnictwo Muzyczne) v Krakovu knjigo z naslovom "Beethovnova polonica» v zvezi z jubilejnim letom 1970 (s t.i. Beethovnovim letom - 200-letnico rojstva velikega skladatelja), sem v njej posvetila posebno poglavje Beethovnovim stikom s Poljaki, živečimi v prvi polovici 19. stoletja na Dunaju, ${ }^{14}$ da bi tako prodrla do morebitnega vira, ki bi bil iz njega mogel Beethoven vzeti avtentične poljske plesne pesmi z njihovimi melodijami in s poljskim tekstom. Govorila sem o varšavskem pianistu Józefu Wölflu, ki je tekmoval $\mathrm{z}$ Beethovnom na zasebnem »tekmovanju « $\mathrm{v}$ improviziranju in $\mathrm{v}$ klavirski igri, o bivanju avstrijsko-češkega pianista Wilhelma Würfla v Varšavi - ta je dolga leta deloval na Poljskem -, dalje o dejavnosti E.T. A. Hoffmanna, ki so ga pruske oblasti pregnale na Poljsko, kjer se je oženil s Poljakinjo in ostal tu mnogo let ter 1806 prvič izvedel v Varšavi Beethovnove simfonije. Nadalje sem se ukvarjala z dunajskimi leti kneza Kleofasa Michała Ogińskega, ki je zaslovel kot avtor sentimentalnih polonez, ter grofa Janusza Iljińskega, poljskega skladatelja, ki se je z njim Beethoven na Dunaju spoprijateljil in imel o njegovi ustvarjalnosti pozitivno mnenje, in slednjič z dunajskim bivanjem kneza Antona Radziwiłła, skladatelja - amaterja s solidnim znanjem skladateljske tehnike, ki je prvi napisal glasbo h Goethejevemu »Faustu«, in še mnogih drugih. Ker se ti glasbeniki niso zanimali za poljsko folkloro in ker so dolga leta živeli v tujini, pač niso mogli biti tisti vir, ki je Beethovnu priskrbel ljudske pesmi. O kakršnikoli zvezah Beethovna s poklicnimi glasbeniki, delujočimi na Dunaju, kakršna sta bila skladatelja Bazyli Bohdanowicz in Jan Kleczyński, nam iz njegove biografije ni nič znanega. ${ }^{15}$ Tudi stiki s saloni poljskih aristokratov (knezov Lubomirskih, grofov Rzewuskih in drugih), ki so živeli na Dunaju v letih pred dunaj-

13 Karol Amenda (1771-1836), duhovnik in odličen violinist, je pripadal v letih svojega bivanja na Dunaju (1788-1799) krogu najožjih Beethovnovih prijateljev. Prisrčno dopisovanje med njima je trajalo 24 let. Njemu je prvemu Beethoven v pismu iz leta 1800 zaupal novico o začetnih pojavih svoje naglušnosti. V pismu s konca poletja 1799 srečamo naslednji Beethovnov pasus: "Gestern hat man mir eine Reise nach Pohlen im Monat September angetragen, wobey mir die Reise sowohl wie der Aufenthalt nichts kostet, und ich mich in Pohlen gut unterhalten kann und auch Geld da zu machen ist, ich habe es angenommen ..."Vendar je iz skladateljevega življenjepisa znano, da te namere ni uresničil in da na Poljskem ni bil. Pismo, ki vsebuje te besede, je iz zbirke A. Kalischerja: Neue Beethoven-Briefe, Berlin-Leipzig, 1902, str. 149.

${ }_{14}$ Z. Lissa, Polonica Beethovenowskie, 1970, Kraków, V.pogl. "Polacy w kręgu Beethovena«, str. 32-53.

${ }_{15} \mathrm{~V}$ odličnih delih Th. v. Frimmla najdemo kompleten seznam oseb, $\mathrm{s}$ katerimi se je Beethoven v svojem življenju stikal, vendar ne srečamo $\mathrm{v}$ njih omenjenih poljskih imen. Th. v. Frimmel, Beethoven-Studien, Bausteine zu einer Lebensgeschichte des Meisters, München-Leipzig, 1905, 2. zv.; isti, Beethoven-Handbuch, Leipzig, 1926. 
skim kongresom (1815), med kongresom in po njem, niso mogli Beethovnu pripomoči $\mathrm{k}$ pridobitvi obeh poljskih pesmi - teh robatih, kar nespodobnih tekstov mu nikakor niso mogli priskrbeti krogi poljske aristokracije. Tako mi je ostala domneva, da jih je Beethoven moral slišati in zapisati od katerega izmed članov poljskih dvornih kapel, ki so jih poljski velikaši pripeljali s seboj na dunajski kongres, tedanji vseevropski shod politikov in državnikov.

Šele po izidu svoje knjige sem naletela na sled, ki daje nedvoumen odgovor na vprašanje, kdo je Beethovnu priskrbel poljska ljudska napeva za priredbo. V letih $1814 / 16$ je živel na Dunaju in se učil klavirske igre pri J. N. Hummlu poljski pianist in skladatelj Franciszek Mirecki, ${ }^{16}$ ki je bil hkrati knjižničar in tajnik poljskega velikaša grofa J. Ossolińskega, znanega bibliofila in zbiralca del s področja poljske umetnosti in kulture. Bila so to tista leta, ko se je Beethoven, pripravljajoč zbirko »Chants des diverses nations«, pritoževal v pismu svojemu edinburškemu založniku, da ima težave pri zbiranju folklornega gradiva nekaterih evropskih narodov. Po prejemu prvega dela teh priredb je Thomson svetoval Beethovnu, naj dopolni svojo zbirko s poljskimi, ruskimi, španskimi in beneškimi pesmimi, ter mu priporočal, naj jih poišče med glasbeniki raznih narodnosti, ki so tedaj živeli na Dunaju. ${ }^{17}$ In prav leta 1816 se je Beethoven, ki je imel neprestane težave s stanovanji in jih $\mathrm{v}$ enem letu po več menjal, na povabilo grofa Ossolińskega preselil $\mathrm{v}$ njegovo palačo. Nastanil se je torej v isti hiši kot Mirecki, ${ }^{18}$ se stikal z le-tem, ki je bil poln občudovanja do velikega skladatelja, in po vsej verjetnosti je od njega dobil folklorno gradivo, ki nas zanima. Ta domneva se spremeni $\mathrm{v}$ gotovost, če pregledamo kores-

${ }^{16}$ Franciszek Mirecki (1791-1862) je študiral klavir pri svojem očetu, hkrati pa tudi filologijo na krakovski univerzi. Od 1814 do 1816 je živel na Dunaju in študiral klavir pri J. N. Hummlu, obenem pa delal kot bibliotekar in sekretar pri grofu Józefu Maksymilianu Ossolińskem. Z Dunaja je odšel v Italijo, kjer se je popolnoma posvetil komponiranju; njegove opere so uprizarjali v Genovi, Firencah, Lisboni, v milanski Scali idr. Leta 1838 se je vrnil na Poljsko, v Krakov, kjer je ustanovil lastno šolo za operno petje ter poučeval tudi $\mathrm{v}$ glasbeni šoli petje in kompozicijo. Leta 1825 je izdal v italijanščini razpravo o instrumentaciji, 1860 pa brošuro, v kateri napada romantike ter brani stil dunajskih klasikov in italijanski operni stil. Napisal je šest oper, eno simfonijo, sonate za violino in klavir, pet klavirskih sonat, variacije, številne zbirke mazurk in krakovjakov ter polonez. Bil je eden maloštevilnih poljskih skladateljev, ki so - pred Chopinom - dosegli priznanje tudi za mejami Poljske.

${ }_{17} \mathrm{~V}$ pismu $\mathrm{z}$ dne 1. I. 1816 piše Thomson: „Je veux beaucoup obtenir quelques échantillons de la musique vocale des differentes nations de l'Europe: de l'Allemagne, de la Pologne, de la Russie, du Tyrol, de la Venise et de l'Espagne. C'est à dire, deux ou trois airs de chacun de ces pays ..... V tem pismu nadalje piše: „Dans une ville comme Vienne, où il y a des musiciens de tous les pays, je crois que vous pourriez trouver sans peine les airs dont je parle ou moins une partie des ces airs«.

$18 \mathrm{O}$ tem poroča St. Estreicher v delu: A. Grabowski, Wspomnienia, Kraków, 1909, II, str. 86. Tudi ta podatek izvira iz korespondence s Fr. Mireckim, čeprav ga ni v njegovih ohranjenih 17 pismih. 
podenco Fr. Mireckega $\mathrm{z}$ Ambrožem Grabowskim iz Krakova; ${ }^{19}$ v pismu z dne 22. IV. 1816 piše: »... kaj me je navdušilo: preden sem začel pisati pismo, sem prejel biljet, v katerem me Beethoven vabi, naj pridem $\mathrm{k}$ njemu $\mathrm{s}$ krakovjaki in njihovimi napevi, gotovo bo kaj poljskega pisal, tega pa sem zmeraj vesel." Ni znano, če je Beethoven tedaj še stanoval v palači grofa Ossolińskega, brez dvoma pa se je, ko je prebival tam, seznanil z Mireckim in navezal z njim ožje stike, tako da mu je lahko poslal ,biljet', ga povabil $\mathrm{k}$ sebi in ga poprosil za poljske plese in pesmi. Ni torej nobenega dvoma več, odk od je Beethoven, ko je prirejal pesmi raznih narodov, dobil gradivo $\mathrm{s}$ področja poljske folklore.

Preden pa preidemo $\mathrm{k}$ nadrobni analizi teh pesmi, posvetimo še nekaj besed usodi celotne zbirke "Chants des diverses nations" in vzrokom, zaradi katerih vse do leta 1941 niti beethovnologom ni bilo o njej nič znanega.

Potem ko je Beethoven poslal celotno zbirko v Edinburg, mu je Thomson $^{20}$ izplačal dogovorjeni honorar, vendar zbirke $\mathrm{ni}$ izdal. Zadrževal je rokopis - ta je bil kopija avtografa, a s to razliko, da je vanjo Beethoven lastnoročno vpisal svoje popravke - vse do leta 1823. Tega leta je odstopil založniške pravice londonski firmi Payne and Hopkins ter ji poslal rokopis, ki mu je dodal svoje založniške pripombe in angleški (prozni) prevod vseh pesemskih tekstov. Toda tudi londonska založniška hiša se ni odločila za izdajo tega dela. Tu se za več kot sto let pretrgajo podatki o usodi rokopisa te zbirke. Šele leta 1926, leto dni pred slovesnostmi ob stoletnici Beethovnove smrti, ko je bil na Dunaju velik muzikološki kongres vseh beethovnologov sveta, so ta rokopis našli $\mathrm{v}$ dunajskem antikvariatu firme V.T. Heck, vendar je zabeležen samo v nemški in ruski literaturi. Celih sto let ni bilo to delo omenjeno v nobenem, niti $\mathrm{v}$ tako zelo obširnem tematskem katalogu Beethovnovih del ne, kakršen je tisti G. Nottebohma ali A. Thayerja,, ${ }^{21}$ prav tako pa ni bilo znano nobenemu od skladateljevih biografov. A niti potem, ko so ta rokopis našli, niso pesmi takoj natisnili. Bežen opis vsebine

19 Prisrčno se na tem mestu zahvaljujem dr. A. Nowak-Romanowiczovi, ker me je opozorila na korespondenco Fr. Mireckega z Ambrožem Grabowskim iz let 1814-1816, ki jo hrani krakovski Arhiv starih aktov (Archiwum Akt Dawnych).

${ }_{20}$ Morebiti je zanimivo in omembe vredno dejstvo, da je Thomson želel dobiti od Beethovna uverture na teme pesmi, ki jih je priredil za omenjeno zbirko. O tem priča pismo (z dne 15. II. 1817), ki $\mathrm{v}$ njem Thomson piše (tokrat po angleško): "I should be glad if you would be good enough to arrange the 19 airs in six ouvertures, in whatever manner seems you best, interwearing them with ideas and passages of your own ... inimitable genius". Thomson omenja tu 19 pesmi, očitno še ni leta 1817 prejel cele zbirke, tj. vseh 24 pesmi.

${ }^{21}$ G. Nottebohm, Thematisches Verzeichniss der im Druck erschienenen Werke von L. v. Beethoven, Leipzig, 1851; 2. izd. 1868; 3. izd. - dopolnil jo je E. Kastner leta 1925 - je pripravil Th. v. Frimmel na Dunaju; A. W. Thayer, Chronologisches Verzeichniss der Werke Ludwig van Beethovens, Berlin, 1865; G. Kinsky und H. Halm, op. cit., izd. 1955 navaja že prve verze teh pesmi. 
odkrite zbirke najdemo $\mathrm{v}$ člančiču W. Lütgena ${ }^{22}$ iz leta 1927 in šele leta 1941 jo je - na podlagi primerjave $\mathrm{z}$ ohranjenimi avtografi in skicami za te pesmi - objavil G. Schünemann v Leipzigu, leta 1956 pa N. Fischmann v Moskvi. ${ }^{23}$

Avtografi obravnavane zbirke (nepopolni) so deloma v Berlinski javni znanstveni knjižnici (Berliner öffentliche wissenschaftliche Bibliothek), ki jih je prevzela iz zbirk Artaria (dunajskega založnika iz Beethovnovih časov), in imajo signaturo 29 II in št. 188; poleg tega sta dve pesmi v Beethovnovi hiši $\mathrm{v}$ Bonnu, $\mathrm{v}$ Beethovnovem arhivu (iz zbirk Heyerja v Kölnu); nekatere so samo fragmenti pesmi ali skice zanje. Kopija, ki so jo našli pri V. Th. Hoecku, je zdaj v Darmstadtu, v Hessenskem deželnem muzeju (Hessisches Landesmuseum). Vrh tega eksistitirajo kopije iz zbirk Breitkopfa in Härtla v Leipzigu.

Beethoven se je od rane mladosti zanimal za folkloro, zlasti za domačo. Zbiral je ljudske pesmi in jih zapisoval v Porenju, pozneje, ko je živel na Dunaju, se je zanimal za avstrijsko folkloro - iz okolice Dunaja, iz Štajerske, Tirolske. Stiki z Rusi, ki so se navduševali nad njegovo ustvarjalnostjo in jo podpirali, so imeli odločilno vlogo pri tem, da se je njegov folkloristični interes razširil tudi na rusko ljudsko ustvarjanje, a dolgoletni stiki z založnikom Thomsonom (od leta 1810) so ga usmerili v angleško folkloro; le-ta je izredno močan in strnjen del njegovega opusa. ${ }^{24}$ Beethoven je zbiral in zapisoval ljudske pesmi do konca svojega življenja. Še leta 1823 , ko je bil ves zatopljen v komponiranje Missae Solemnis, je pisal v Bonn svojemu založniku Simrocku, ko mu je sporočal, da mu pošilja priredbe avstrijskih pesmi (pismo z dne 18. III. 1823): "... ich denke, eine Volksliedjagd ist besser als eine Menschenjagd der so gepriesenen Helden .....

Res je imelo uporabljanje ljudskih melodij, zlasti nemških v Beethovnovi ustvarjalnosti - kot pišeta E. H. Meyer in G. Kraft ${ }^{25}$

${ }^{22}$ W. Lütgen, Bericht über ein neuaufgefundenes Manuskript, enthaltend 24 Lieder (verschiedener Völker), von Beethoven, v: "Der Bär«, letnik 1927, str. 160-165; W. Hess, "52 ungedruckte Volksliedbearbeitungen Beethovens", v: »Schweizer Musikzeitung", 1936; že prej je isti avtor objavil članek "Neues zu Beethovens Volksliedbearbeitungen, v: "Zeitschrift f. Musikforschung", 1931, XIII. zv., str. 317-321. Leta 1970 je W. Hess izdal XIV. zvezek "Supplements zur Gesamtausgabe« Beethovnovih del, kjer je priobčil vse prej neznane, na novo odkrite Beethovnove pesmi, med 57 tudi tu obravnavano zbirko.

${ }_{23}$ G. Schünemann, Beethoven - Neues Volksliedheft, Leipzig, 1941, Breitkopf und Härtel; N. Fischmann, L. Beethoven - pesni raznyh narodov, Moskva, Muzgiz, 1959.

${ }^{24}$ To so zbirke: 12 irskih pesmi, 1813; 20 irskih, 1813; 25 irskih, 1813; 12 angleških, italijanskih in drugih pesmi, $1815 ; 12$ škotskih, 1815, 25 škotskih, 1815; 26 waleških, 1817; poleg tega 56 posebej datiranih pesmi; $\mathrm{k}$ temu je treba prišteti angleške pesmi, ki so tudi v zbirki 24 pesmi raznih narodov, 1816-1818. Naposled so našli (W. Hess, op. cit.) vrsto neznanih pesmi, skice za nedokončane pesmi itp.

${ }^{25}$ E. H. Meyer, Beethoven und die Volksmusik, v: »Aufsätze über Musik«, Berlin, 1957; G. Kraft, L. v. Beethoven, v: "Festschrift des Beethoven-Ausschusses«, Ehrfurt, 1952. 
- precejšnjo vlogo, posebno v oblikovanju tematskih zamisli, vendar pa so bile priredbe ljudskih melodij zanj samo stranski proizvod, le na robu njegovega ustvarjanja velikih simfoničnih oblik, komorne in klavirske glasbe. Takšnega bistvenega pomena, kakršnega je folklora dobila za estetsko zavest in skladateljsko tehniko romantikov in kasnejših rodov (Chopin, Musorgski, Grieg, De Falla, Bartók in drugi), za Beethovna še ni imela. Če je pri omenjenih skladateljih segala prav $v$ osnove njihovega glasbenega mišljenja, za Beethovna tega nikakor ni mogoče ugotoviti. Beethoven je vključil ljudsko blago raznih narodov $\mathrm{v}$ svojo skladateljsko tehniko, ni pa mu podredil svojih metod oblikovanja. Nasprotno, te metode je celo močno poenostavil, ker se je popolnoma zavedal vloge - danes bi rekli družbene funkcije - ki naj bi jo imela ta zvrst ustvarjalnosti. Zato se pojavljajo pri njem daljnosežne analogije v prirejanju narodnostno različnih ljudskih melodij. Njihovo skupno število ceni Kinsky v svojem tematskem katalogu na 152, J. Schmidt-Görg ${ }^{26}$ na »weit über 200, die wohl nicht nur als Brotarbeit zu werten sind...». Danes imamo na podlagi vseh doslej odkritih avtografov pravico govoriti skupno o 176 delih tega tipa ter o številnih skicah za nameravana, a ne napisana dela te vrste. Nastajala so v letih $1810-1823$, a posebno številna so $\mathrm{v}$ letih $1813-1818$, ko sta bili napisani tudi priredbi poljskih pesmi.

Preden začnemo bolj nadrobno obravnavati ti dve pesmi, je morda vredno omeniti, da lahko razen le-teh ugotovimo v Beethovnovi tvornosti večje število polonik. To so predvsem instrumentalne poloneze ter druga dela $\mathrm{z}$ izrazito poudarjenimi značilnostmi poloneze, čeprav nimajo naslova te zvrsti. Nimajo vselej oblike samostojnega dela, izredno pogosto so - po tradiciji iz 18. stoletja sestavni del sonatnega ali kakšnega drugega cikla. Toda med njimi so že tudi oddeljene, samostojne poloneze virtuoznega značaja, ki že napovedujejo poloneze K. M. Webra, kot npr. Klavirska poloneza 1522

26 J. Schmidt-Görg, Beethoven, v: MGG, I, Kassel, 1949-1951, stolpec

${ }_{27}$ Poloneze ima Beethoven $\mathrm{v}$ naslednjih delih: 1 . Sonata za flavto in klavir v b-duru, brez opusa; poloneza je vstavljena med I. del in largo. Nastala je pred letom 1792; Beethovnovo avtorstvo ni popolnoma dokazano; 2. v Trio-serenadi v d-duru, op. 8, za violino, violo in violončelo iz 1795/6 je Allegretto alla Polacca kot 6. del v osemdelnem ciklu; napisan je v f-duru; 3. v Klavirskih variacijah na temo F. Winterja "Kind, willst du ruhig schlafen", v f-duru, brez op.; variacija 7 -a, tik pred kodo, je poloneza, čeprav nima tega naslova; 4. v Trojnem koncertu (Tripel-Konzert) za violino, violončelo in klavir $\mathrm{z}$ orkestrom, op. 56 , v c-duru je finale Rondo alla Polacca; delo je bilo napisano v letih $1804 / 5 ; 5$. Menuet iz Godalnega kvarteta št. 3, op. 59, v c-duru je pravzaprav poloneza; 6. Poloneza za pihalni orkester v d-duru, brez op., je nastala leta 1810, po naročilu; 7. Poloneza za klavir solo v c-duru, op. 89, skomponirana leta 1814, je velika, virtuozna oblika poloneze že v takem stilu kot obe Webrovi polonezi. Poleg tega imajo izrazit značaj poloneze številni menueti in plesi brez podnaslovov kot npr.: Gratulations-Menuett za orkester, brez op., iz let 1822/3, ki so ga našli med skladateljevimi rokopisi po nje- 
v c-duru, op. $89 .{ }^{27}$ Beethovnove poloneze zavzemajo prehodno mesto med baročno polonezo 18. stoletja in osamosvojeno zvrstjo koncertnega značaja, vendar kažejo že poznejšo, za polonezo tipično ritmiko spremljave. Pripravljajo tla za popolno osamosvojitev te plesne oblike in za spremembo njenega značaja, kakršna se zgodi $v$ celoti šele $v$ Chopinovi ustvarjalnosti.

Poljski pesmi, ki sta predmet naše sedanje obravnave, pa nista polonezi; to sta za poljsko folkloro najbolj značilni pesmi plesnega značaja: ena je tipičen $\mathrm{krakovjak}$, druga pa nič manj tipičen oberek, tj. hitra inačica mazurke. Obe zvrsti sta do danes v vseh poljskih pokrajinah močno razširjeni.

Obe poljski melodiji, ki ju je priredil Beethoven, spadata med tiste maloštevilne tuje zapise poljske folklore, ki $\mathrm{n}$ i s o znani v nobenem domačem zapisu v taki obliki, v kakršni nam jih je sporočil skladatelj. Ni ju niti v največji zbirki poljskih ljudskih pesmi O. Kolberga, ${ }^{28}$ niti v kakšni pomembnejši poznejši. Namesto tega pa najdemo njune variante $\mathrm{v}$ številnih kasnejših zapisih, $\mathrm{v}$ glavnem variante samega teksta, v manjši meri variante melodike. Precejšnja geografska razkropljenost teh variant kaže na splošno poznavanje motivov, a hkrati tudi na njihovo nestabilnost.

Beethovnova verzija krakovjaka v $2 / 4$ taktu skupaj s tekstom:

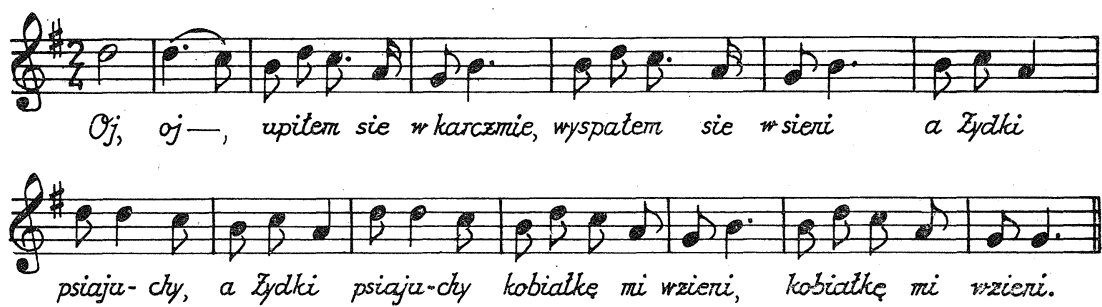

govi smrti; sedmi od 12 menuetov za orkester iz let 1795/99 ima izrazite poteze poloneze 18. stoletja, podobno kot drugi od 11 Möglinger-Tänze iz leta 1819, ali pa tema Klavirske sonate v es-duru, op. 31, ki lahko zbuja asociacije na polonezo. Nadalje lahko v Beethovnovi ustvarjalnosti najdemo poteze, značilne za polonezo, $\mathrm{v}$ raznih delih, napisanih $\mathrm{v}$ parnih taktih s poudarjeno tipično »bolero" ritmiko poloneze. Takih primerov je precej in kažejo na to, da se morejo ritmične značilnosti nekega plesa včasih pojaviti v okviru drugačne metrične strukture. To je vprašanje, s katerim se bomo kdaj posebej ukvarjali: polonezina ritmika in faktura spremljave ali polonezine značilnosti kadenčnih obratov se utegnejo pojaviti na mreži $2 / 4$ ali $4 / 4$ takta, kar lahko opazimo v celi vrsti Beethovnovih (in ne samo Beethovnovih) del.

28 O. Kolberg, Lud, jego zwyczaje, sposób życia, mowa, podania, przysłowia, obrzędy, gusła, zabawy, piesni, muzyka i tańce. V 37 zvezkih, ki so izhajali v letih 1865-1890. Rokopisna zapuščina obsega nadaljnjih 10 zvezkov. Od 1961 izhaja nova, izpopolnjena izdaja tega velikanskega dela. - Poljsko ljudsko blago so začeli zbirati v zač. 19. stoletja (J. Lelewel, T. Czacki, J. Woronicz, Z. Dołęga-Chodakowski, K. Wójcicki in dr.), vendar te zbirke za skladateljevega življenja niso bile objavljene in Beethoven ni mogel imeti dostopa do njih. 
Razlike $\mathrm{v}$ besedilu te pesmi so neznatne:

varianta a)

Upitem sie $w$ karczmie wyspatem sie $w$ sieni

psie bestyje Żydy

kosyk mój mi wzieni.

varianta $b)$

$0 j$, upitem sie $w$ karczmie

wyspatem sie $w$ sieni

a moj žydkowie

kobytke mi wzieni.

varianta c) razvija isto vsebino $\mathrm{v}$ dveh kiticah:
Wypitem sie $w$ karczmie
przespatem sie $w$ sieni
$O j$, żydzi, kanalije
kobiatke mi wzieni.
Żydzi, kanalije
oddajcie kobiatke
Oj, cemze bede nosiut
krupy na gorzatke?

Kar se tiče glasbene strani, ima danes to besedilo včasih metrum in ritmiko oberka $\mathrm{v} 3 / 8$ taktu namesto prvotnega krakovjaka v 2/4 taktu, to pa povzroča številne premike besednih naglasov na zadnje zloge besed.

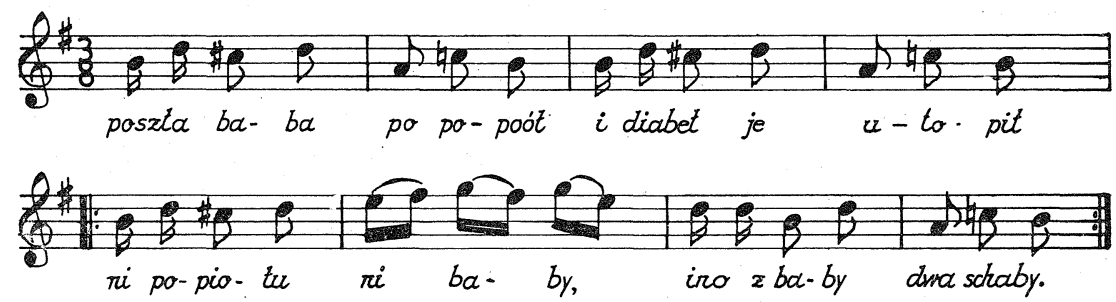

Druga pesem, pri Beethovnu tipa oberek v 3/8 taktu, se prav tako pojavlja $\mathrm{v}$ različnih variantah tekstne in melodične narave. Varianta iz druge polovice 19. stoletja, samo tekstna:

varianta a)

Poszta baba po popiót

diabet babe utopiót

baba diabta odesta

bo nie umiat rzemiosta. 
varianta b) (iz začetka 20. stoletja):

Poszla baba po popiót, po popiót, po popiót diabet babe utopiót, utopiót, utopiót a $z$ popiotu $i$ baby, i baby, $i$ baby zrobilo sie trzy żaby, trzy żaby, trzy żaby.

Manjših besednih variant, kjer je namesto besede »diabeł" beseda ,kaduk', ne bomo navajali. Medtem pa se melodične variante tako zelo razlikujejo od njihovega vzorca iz Beethovnovih časov, da je težko govoriti o kakršnikoli podobnosti s prvotno verzijo. Za primer dajemo po eno varianto obeh obravnavanih pesmi: krakovjak » $\mathrm{Oj}$, upiłem się w karczmie" je postal oberek, in obratno - oberek »Poszła baba po popiół« se je spremenil v krakovjak:

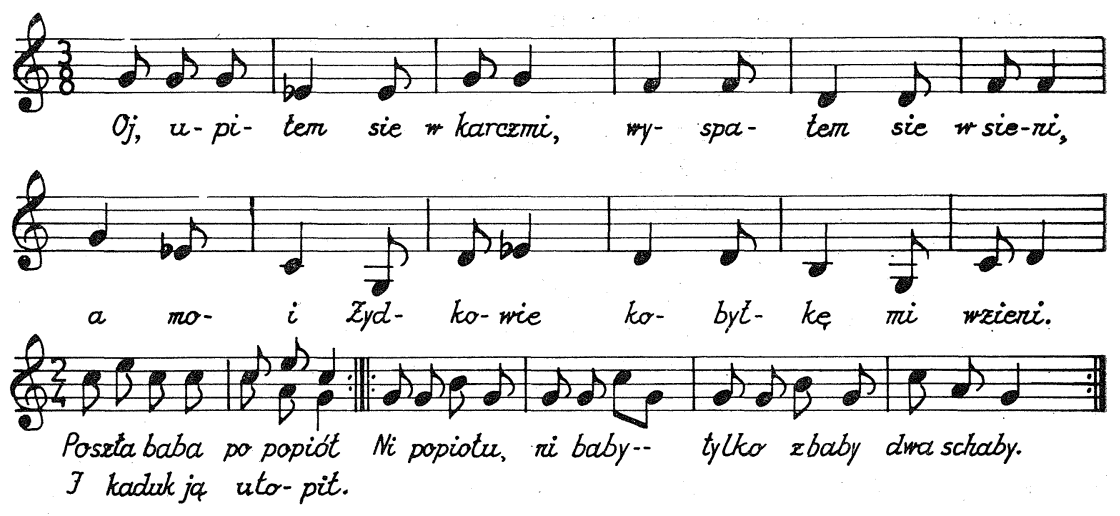

Kot vidimo, sta ti dve pesmi med več kot stoletnim popotovanjem po raznih poljskih pokrajinah doživeli dvojen proces: prvi - le neznatnih tekstnih odklonov, ki ne rušijo osnovnih motivov, temveč jih samo zaostrujejo ali razširjajo v primerjavi s tekstom, kakršnega je Mirecki posredoval Beethovnu in ki so ga $\mathrm{v}$ začetku 19. stoletja gotovo splošno peli; drugi - odcepitev teksta od njegove prvotne melodije, še več - korenito spremembo metrično-ritmičnega značaja, tako da je krakovjak postal oberek, oberek pa krakovjak. Tekstne spremembe kažejo težnjo po okrepitvi ekspresivnosti: ukradena "kobiałka» (košara) je postala bolj dragocena stvar, namreč ukradena kobyłka (kobilica), "psie bestyje« (pasje beštije) pa so se spremenile v bolj pejorativne ,kanalije' (kanalje).

O splošni razširjenosti oberka »Posła baba po popiół« priča po drugi strani dejstvo, da so nekatere njegove formulacije prešle kot navaja S. Adalberg v svoji »Knjigi pregovorov«, ${ }^{29} \mathrm{v}$ zakladnico poljskih ljudskih pregovorov.

Obe pesmi, ki ju je Beethoven izbral - gotovo iz mnogih drugih, ki mu jih je predložil F. Mirecki leta 1816 - in njune variante

${ }^{29}$ S. Adalberg, Księga przysłów, przypowieści, i wyrazów przysłowiowych, Warszawa 1889-1894, str. 68, 84 in dr. 
pričajo, da so bile že $\mathrm{v}$ tistem času resnično ljudski pojav, tipičen za poljsko folkloro, in da je skladatelj dobro začutil njun reprezentativni značaj, in prav to je odločilo o njegovi izbiri. Dejstvo, da avtograf in kopije zbirke "Chants' des diverses nations" navajajo samo po eno kitico njihovega besedila, kaže na to, da Mirecki ni poznal ali ni pomnil drugih kitic, ko je pripovedoval Beethovnu obe pesmi ,iz glave', na pamet.

Zanimivo je, da odsevajo $\mathrm{v}$ Beethovnovih priredbah vse tipične značilnosti izvajalskih načinov, ki so lastne igri poljskih ljudskih godb in izvajanju poljskih plesnih napevov. Težko je zdaj ugotoviti, koliko je to bilo posledica neposrednega stika $\mathrm{z}$ izvajalci: o tem bi raje dvomili, razen če dopustimo, da bi bil mogel skladatelj slišati katero od velikaških kapel, ki so jih poljski velikaški dvori pripeljali s seboj na Dunaj. Prej je tudi v tem treba videti ,kolegialne' nasvete Mireckega, ki je tedaj izdal pri Artarii svoje »Mazurke« op. 5 in gotovo ustregel Beethovnovemu povabilu, naj bi »skupaj s svojimi krakovjaki in njihovimi napevi« (prej citirano pismo Mireckega A. Grabowskemu z dne 22. IV.1816 z Dunaja) obiskal svojega starejšega stanovskega tovariša. Vse drugo je bilo stvar genialne Beethovnove intuicije.

Dejstvo je, da se Beethovnove priredbe poljskih ljudskih pesmi precej izrazito ločijo $\mathrm{v}$ svoji fakturi, $\mathrm{v}$ tonalno-harmonskih značilnostih od bolj stereotipnih in istovrstnih priredb ljudskih pesmi drugih narodov $\mathrm{v}$ isti zbirki. Seveda tudi te ne segajo prek najbolj preprostih sredstev klasičnega stila, podobno kot prirejeni poljski plesi, ki so jih $\mathrm{v}$ tej dobi izdali na Poljskem. ${ }^{30}$

$\mathrm{V}$, čem so torej tiste značilnosti obeh Beethovnovih poljskih pesmi, ki so lastne poljski folklori in njenim obdelavam?

Kot smo že prej omenili, imata pesmi za poljsko folkloro najbolj tipični plesni melodiji: krakovjak in oberek. Obedve sta podani v g-duru, obedve sta - kot cela zbirka "Pesmi raznih narodov", pa tudi večina škotskih, waleških, irskih in drugih pesmi - prirejeni za glas ob spremljavi violine, violončela in klavirja. Taka oblika izvajanja je bila prikladna za tedanje domače muziciranje: instrumentalni ansambel je majhen, a raznolik, celota izkorišča vokalna in instrumentalna sredstva, od teh zadnjih - dva instrumenta kantilenskega tipa, violino in violončelo, ki se lahko samobitno zoperstavita vokalnemu partu. Vsi trije instrumenti so bili v tedanjih glasbeno aktivnih hišah popularni, njihova povezava pa dobro znana iz oblik komorne glasbe, ki so jo splošno gojili kot ,Hausmusik'. Človeški glas predstavlja tu ljudsko pristnost $\mathrm{s}$ tekstne in $\mathrm{z}$ glasbene strani.

Podčrtati je treba, da so tega tipa izvajalsko opremo dajali svojim priredbam ljudskih pesmi tudi Haydn, Pleyel, Koželuch in drugi, ki so pisali za Thomsonovo in druge založbe. Če so založniki zahte-

30 Najstarejša natisnjena zbirka priredb "Pesmi gališkega ljudstva" (avtor Karol Lipiński) obsega 24 pesmi, vključenih $\mathrm{v}$ knjigo Wacława $\mathrm{z}$ Oleska z enakim naslovom (II. del), ki je izšla v Lvovu 1833. 
vali te vrste zasedbo, je morala biti za tisti čas najbolj funkcionalna, tj. ustrezati je morala potrebam muzicirajočega meščanstva, normam intimnega, domačega, salonskega muziciranja. Pomnimo namreč to, da $\mathrm{v}$ začetku 19. stoletja priredbe folklore še niso tako napredovale, da bi prišle na odre javnih koncertov. Sprejemanje različnih glasbenih zvrsti je bilo $v$ tem času še družbeno pogojeno, tj. zdiferencirano za razne sloje. Miniaturna oblika, njena kritičnost, razširjenost ljudskih melodij in razmeroma precej preprosta sredstva njihove obdelave razločno kažejo družbeni obseg in družbeno funkcijo opisane glasbene zvrsti: zadoščala je določenemu tipu potreb tedanjega meščanstva in to $\mathrm{v}$ glavnem tistih njegovih krogov, ki še niso toliko dozoreli, da bi sprejemali velike forme, ustvarjene s kompliciranimi skladateljskimi sredstvi. Vsaka doba ima očitno svojo družbeno stratifikacijo glasbenih oblik in zvrsti, ki zadovoljujejo glasbeno manj izšolane poslušalce.

Dejstvo, da je poleg drugih komponistov tudi Beethoven na to družbeno potrebo svojega časa tako močno reagiral, dokazuje ne samo to, kar pravi R. Aldrich, ${ }^{31}$ namreč, da je pisal zaradi kruha in da je spričo nestabilnosti tedanje dunajske valute poznal in pravilno cenil vrednost angleškega funta, ampak da se je tudi zavedal vloge te zvrsti, ki jo je, kot sam piše Thomsonu (v pismu $\mathrm{z}$ dne 17. VII. 1810), gojil »con amore«.

$\mathrm{Da}$ je Beethoven odlično zadel značilnosti poljske glasbene folklore, $\mathrm{v}$ svojih priredbah obeh pesmi, se vidi tako $\mathrm{v}$ tonalno harmonskih lastnostih kot $\mathrm{v}$ fakturi spremljave, najbolj pa $\mathrm{v}$ metrično-ritmičnih značilnostih obeh pesmi. $\mathrm{V}$ koliko so na to vplivali nasveti Fr. Mireckega, koliko pa je bilo v tem lastne skladateljske intuicije, je težko reči. Dejstvo pa je, da sta $v$ mnogih svojih lastnostih izjemni v primerjavi $\mathrm{z}$ vsemi drugimi pesmimi te zbirke, da sta veliko bolj kot druge nasičeni $\mathrm{z}$ atmosfero "pristnosti«.

V krakovjaku se za poljsko folkloro tipična lidijska kvarta pojavi $\mathrm{v}$ basu in je tem bolj izrazita, ker je $\mathrm{v}$ vokalu čista kvarta.

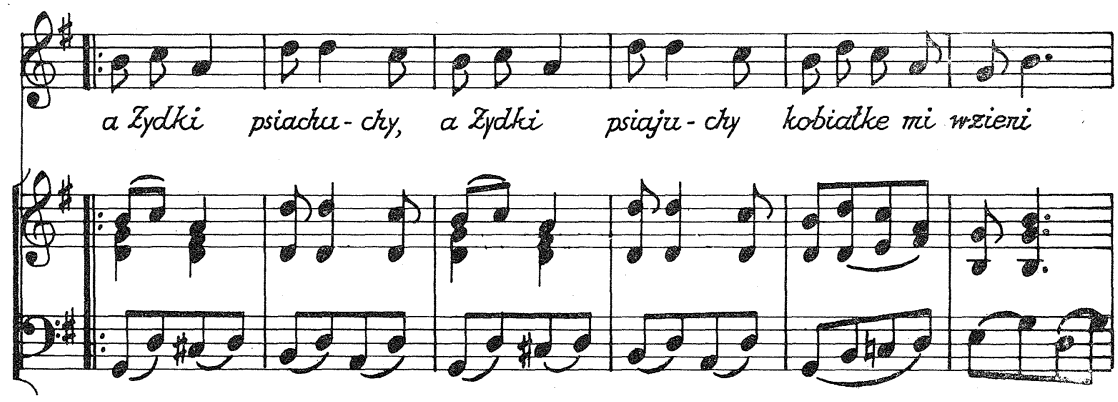

${ }^{31}$ R. Aldrich, Beethoven and Thomson, v: "Music and Letters", London, VIII, 4. zv., str. 242: "... the composer's eye firmly fixed on the English pound sterling... when the values such as the ,Wiener Währung' were crumbling..... 
Sama melodija te pesmi namreč nima »lidizmov«. Zato pa se v drugi pesmi, v oberku, za melodiko poljskih ljudskih pesmi tipično moduliranje zvečane in čiste kvarte velikokrat pojavi; skladatelj prenaša poleg tega »lidizme« v parte vseh treh instrumentov spremljave:

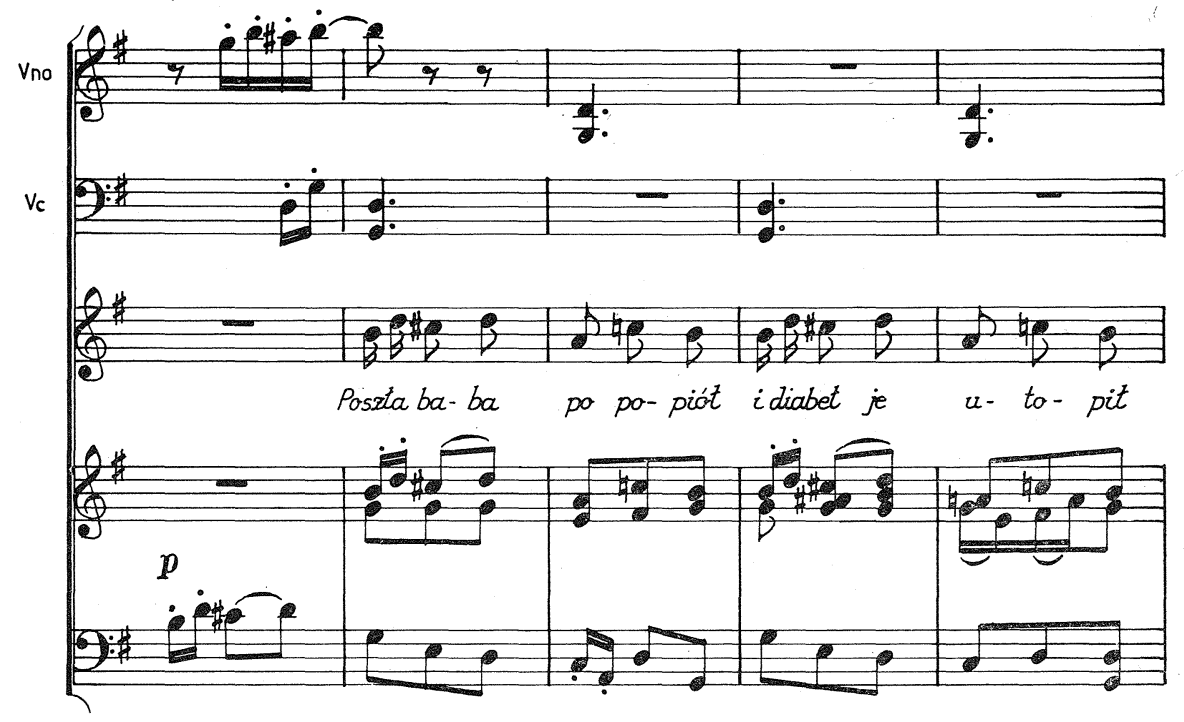

Harmonika obeh priredb v osnovi ne presega sredstev precej primitivne diatonike $\mathrm{s}$ prehodnimi nagnjenji $\mathrm{k}$ tonalnosti subdominante $\mathrm{v}$ krakovjaku (t.6) in s prav tako prehodnimi kromatizmi menjalnih tonov, vodečih $\mathrm{v}$ oberku (t. $5,8,11,14$ idr.). Če se zavedamo, da sta priredbi obeh poljskih pesmi nastali že potem, ko je Beethoven napisal Sedmo in Osmo simfonijo, Appasionato in Uverturo k Fideliu, ter le malo pred zadnjimi kvarteti, si moremo naivnost sredstev $\mathrm{v}$ opisanih priredbah razložiti samo $\mathrm{z}$ zavestno omejitvijo le-teh, ker je skladatelj imel občutek za družbeno mesto te vrste ustvarjalnosti in za naloge, ki naj bi jih izpolnjevala v čisto določeni skupini poslušalcev. Ni pa še prišel čas za to, da bi iz modalnih osnov folklore izvajali tehnične konsekvence, zlasti v harmoniki ne; folklora tedaj še ni tako napredovala na lestvici glasbenih vrednot kakor pozneje, pri skladateljski generaciji, ki je prišla za Beethovnom - pri romantikih, še posebno pa pri predstavnikih narodnih šol. To je bila šele pridobitev Chopina, Glinke in poznejših skladateljskih rodov. Harmonske inovacije je uvedel Beethoven edinole na področju svojih velikih form - simfoničnih ali komornih in klavirskih - in to predvsem $\mathrm{v}$ preoblikovalnih partijah.

Stilizacija v ljudskem duhu se kaže v obeh poljskih pesmih v uporabi številnih ležečih glasov, bodisi v obliki posameznega glasu ali v obliki praznih, burdonskih kvint (krakovjak t.11-24, oberek t. $1-7,10-15)$. Pojavlja se to ali $\mathrm{v}$ violinskih ali $\mathrm{v}$ violončelskih ali v klavirskih partih. Godala ustvarjajo burdone s harmonsko-kolori- 
stično funkcijo in so kot taka središča za druge glasove. Posnemajo tipično izvajalsko prakso poljskih kmečkih godb. Ti instrumenti nimajo $\mathrm{v}$ nobeni od obeh pesmi funkcije vodilnih glasov $\mathrm{v}$ melodiji, le $\mathrm{v}$ nekaterih odsekih oberka dublirajo $\mathrm{v}$ tercah vokalni glas ali pa ga krepijo v oktavah. V krakovjaku so omejeni skoraj izključno na funkcijo burdona. Vlogo burdona kot sredstva za stilizacijo ljudske pristnosti in ljudskih izvajalskih načinov je treba tu posebno močno podčrtati, kajti Beethoven ga je uporabil izključno le v poljskih pesmih omenjene zbirke, ni pa tega storil v nobeni pesmi drugih narodnosti, zlasti če gre za burdon prazne kvinte. Bežno se pojavi posamezen ležeči glas v kozaški pesmi, ostinato pa v švedski, a tu bolj kot značilnost uspavanke. V nobeni drugi pesmi omenjene zbirke ne sodeluje faktura klavirskega parta po istih načelih $\mathrm{s}$ partom violine in violončela kot $\mathrm{v}$ poljskih pesmih. To bi kazalo na skladateljevo tendenco, da podčrta njuno narodno specifikacijo.

Posebno močno pa se pojavlja ta tendenca na področju metrično-ritmičnih sredstev, označenih z ritmiko samih prirejenih melodij. $\mathrm{Tu}$ so torej številne sinkope raznih tipov v krakovjaku

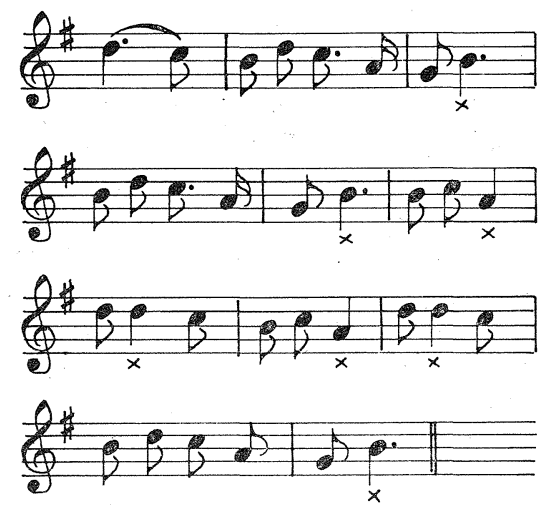

ter pogosto premikanje taktnega akcenta na drugi ali tretji del takta (po načinu plesov mazurkinega tipa) v oberku, ali pa razbijanje prve osminke takta na manjše enote, ki slabijo taktni akcent:

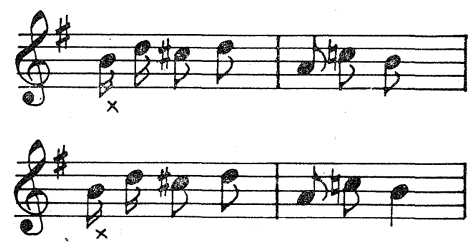

Obe pesmi imata instrumentalen uvod, ustrezajoč ljudski, čisto instrumentalni introdukciji pred začetkom petja: krakovjak 10-taktni, oberek pa 8-taktni uvod. Poleg tega pa prav tak instrumentalen konec: krakovjak 13-taktni, oberek pa 12-taktni. V uvodih in sklepih 
so izkoriščeni motivi vokalnega glasu, včasih celo $\mathrm{z}$ uporabo imitacije ali $s$ figuracijskim razvitjem motivov in $z$ močnejšo zvočno nasičenostjo:

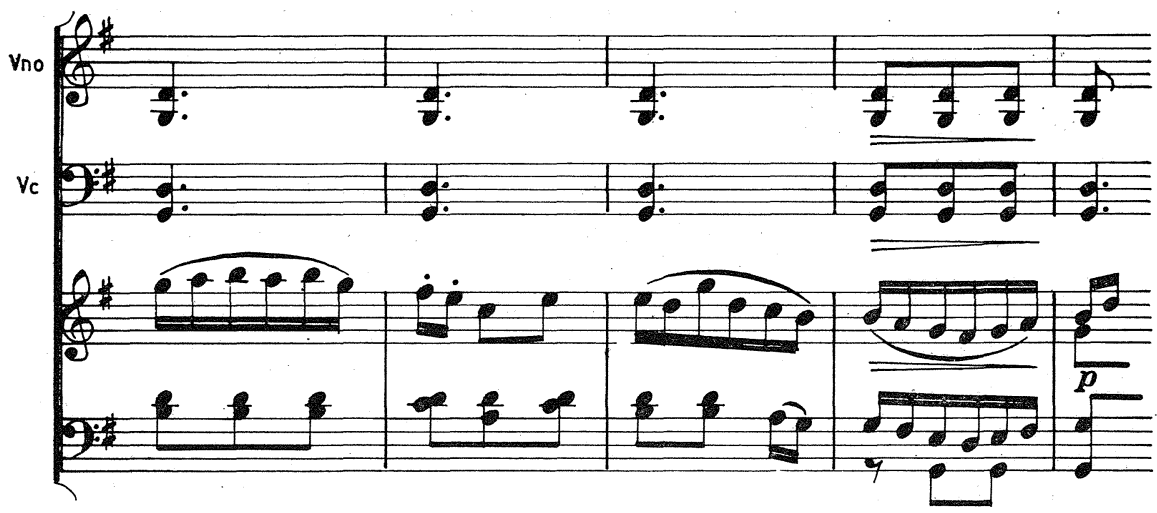

Vokalni part je v krakovjaku 8-taktni stavek, v oberku prav tako, s ponavljanjem drugega štiritaktja. Poljski tekst sestoji iz ene same kitice. Ni znano, ali je Beethoven računal na dopolnitev tekstov, ki mu jih je posredoval Fr. Mirecki, ali pa je predpostavljal, da bo tekst $\mathrm{v}$ angleškem oziroma nemškem prevodu bolj razvil vsebino prvih kitic. Vemo le, da je bil v kopiji rokopisa, ki jo je poslal Thomsonu, s a mo poljski tekst, rokopis, ki so ga našli leta 1926 pa vsebuje tudi dopisani - sicer le filološki - angleški prevod, medtem ko nemškega prevoda tu ni. V izdaji G. Schünemanna iz leta 1941 je poleg poljskega nemški tekst (prevedla ga je neka Alice Klengel, tako kot vse druge tekste te zbirke), ki pa se popolnoma razlikuje od precej sočne, že kar robate vsebine izvirnika. V revizijskem komentarju $\mathrm{k}$ svoji izdaji ugotavlja Schünemann tudi to, da rokopis zbirke "Pesmi raznih narodov«, izvirajoč iz arhiva Artaria na Dunaju, sploh nima nobenega vpisanega teksta. Ali torej prevajalka ni razumela teksta, ker ni znala poljsko, ali pa se je hotela iz priderije izogniti njegovim ostrim tematskim poudarkom, ni znano. ${ }^{32}$ Vsekakor lahko dopuščamo, da Beethoven teh prevodov ni poznal. Saj vemo iz Beethovnove korespondence $\mathrm{s}$ Thomsonom, ${ }^{33}$ da je skrbel za avtentičnost besedila in da je temu pripisoval velik pomen: $v$ korespon-

${ }^{32}$ Nemški prevod obeh poljskih pesmi:

a) krakovjak:

Auf, auf ihr Freunde

laßt im Wein uns den Gram ertränken!

Mag mein Lieb untreu sein,

b) oberek:

Das soll mich nicht kränken!

Lenz- und Liebeswonne enden

Kaum begonnen,

Koste aus die frohe Zeit

Ehe sie verronen! 
denci v zvezi s škotskimi pesmimi podčrtuje pomen teksta za pravilno glasbeno interpretacijo pri prirejanju folklore.

Natančno prilagajanje glasbenih akcentov tekstnim $\mathrm{v}$ poljskem izvirniku celo tam, kjer so $\mathrm{v}$ duhu ljudskih pesmi jezikovni naglasi podvrženi premikom, in celo natančni logični akcenti v stavkih besedila, bi kazali na to, da je skladatelj, ko je prirejal ti dve pesmi, poznal njuno avtentično vsebino, še več - da ga je kakšna vešča roka podpirala pri najustreznejšem razporejanju teh akcentov. Celo več - lahko dopuščamo, da je kdo informiral skladatelja o »za poljsko folkloro tipičnih « premikih jezikovnih naglasov v ljudski, peti verziji tekstov. Ni težko tudi v tem spoznati ingerenco Fr. Mireckega. Nemški in angleški prevod sta bila poz n e j e dodana; ko je Beethoven prirejal poljski pesmi, se je ravnal samo po obeh poljskih tekstih, ki mu ju je moral prevesti Mirecki. Ker poznamo njegovo korespondenco in njegov neposredni način izražanja (zlasti iz njegovih doslej izdanih konverzacijskih zvezkov, ${ }^{34}$ ga je težko osumiti priderije in želje izogniti se robatim izrazom ljudske pristnosti. Sicer pa lahko ob tem dodamo, da prevodi pesmi drugih narodov iz te zbirke prav tako grešijo $\mathrm{v}$ netočnosti in $\mathrm{v}$ nerazumevanju duha folklore.

Tega ne moremo očitati Beethovnu, ko gre za glasbeno obdelavo teh pesmi, še posebno poljskih: te priredbe dokazujejo, da se je skladatelj na vso moč trudil, da bi podčrtal njihov svojski značaj, tako $\mathrm{v}$ tonalni osnovi kot $\mathrm{v}$ fakturi spremljave in $\mathrm{v}$ ritmično-metričnem pogledu. Seveda ju je pri tem obravnaval v stilu svoje dobe in svoje generacije, in to - kakor smo že omenili — v takem stilu, ki je bil glede sredstev opazno poenostavljen v primerjavi z drugimi njegovimi deli in v razmerju do njegovih možnosti. Jasno je, da skladatelj $\mathrm{v}$ tej zvrsti glede na njen namen in na miniaturno formo ni mogel v celoti razviti svojih kril.

$\mathrm{Na}$ koncu je treba še enkrat podčrtati, da je pokazal Beethoven v priredbi poljskih pesmi veliko več občutka za njihov stil kot pri drugih slovanskih pesmih (4 ruskih in 1 ukrajinski), ki prav tako sestavljajo zbirko »Pesmi raznih narodov«.

$\mathrm{Za}$ poljsko glasbeno kulturo je velikega pomena, da se je $\mathrm{v}$ interesnem krogu velikega nemškega skladatelja našlo mesto tudi za poljsko folkloro in da je poljski kulturi in njenim tradicijam poklonil dar v obliki opisanih priredb dveh ljudskih pesmi ter vrste polonez. Slednji problem pa obravnavam $\mathrm{v}$ posebni študiji. ${ }^{35}$

${ }^{33}$ To se vidi iz vsebine njegovih pisem, $\mathrm{v}$ katerih ponovno prosi Thomsona, naj mu pošilja angleške pesmi $z$ izvirnimi besedili: »...je vous prie d'ajouter dans l'avenir toujours les textes« piše $\mathrm{v}$ pismu $\mathrm{z}$ dne 20. VII. 1811; to prošnjo ponavlja $\mathrm{v}$ kasnejših pismih $\mathrm{z}$ dne 3. XII. 1812, 8. VII. 1816 in 17. II. 1817, torej prav v času, ko je prirejal »Pesmi raznih narodov«.

${ }_{34}$ L. v. Beethovens Konversationshefte, izd. K. H. Köhler in G. Herre, V, Leipzig, 1970.

35 Z. Lissa, Beethovens Polonaisen, v: Beiträge zur Musikwissenschaft, Berlin, 1970, zv. 3-4. 


\section{SUMMARY}

At the turn of the 18th and 19th centuries the middle classes of western Europe became aware of a need for many kinds of music which, in previous centuries - in a different social order - had not played any really important role in musical life. Although they do not belong to the history of so-called "great music", the arrangements of folk songs of various European nations represent one of these kinds. Such arranging was undertaken by J.Haydn, J.A. Koželuch, J. N. Hummel, I. Pleyel and not least by Ludwig van Beethoven, mostly from the year 1810 on. His arrangements of Scottish, Irish and Welsh songs are well known. However, until recently it was not known that in 1816-1818 Beethoven also wrote arrangements for 24 songs of various European nations, in the collection "Chants des diverses nations", which includes several Slavonic songs: 2 Polish, 4 Russian and 1 Ukrainian.

On one hand the arrangements of the two Polish songs reflect the interest in "goût polonais", which was especially strong in Germany in the 18th century, while on the other they bear witness to Beethoven's great interest in folklore. For many years the authoress was faced with the apparently insoluble problem of where did Beethoven find the source for the Polish melodies: there were no printed collections of Polish folklore before 1816, while Beethoven's contact with Polish musicians living in Vienna was slight; besides this the composer had never been to Poland. His contact with the salons of Polish aristocrats living in Vienna in the years before the Vienna congress (1815), during the congress and after it would not have helped Beethoven to obtain the two Polish songs either, as the circles of Polish aristocracy could not possibly have provided him with such coarse texts. So there remained only the possibility that Beethoven must have heard them (and written them down) from one of the members of the court orchestras which the Polish dignitaries had brought with them to Vienna. The trail led on to the Polish pianist and composer Franciszek Mirecki, who lived in Vienna from 1814-1816 and studied piano under J. N. Hummel. Mirecki was also the librarian and secretary to the Polish Count J. Ossoliński and in 1816 Beethoven, who had continual troubles with living accomodation, moved into the palace at the invitation of the count. The hypothesis is confirmed by a letter from F. Mirecki to A. Grabowski, dated 22.4.1816.

The two Polish songs that are the object of this article represent the most characteristic dance tunes of Polish folklore: one is a typical krakowiak, the other a not less typical oberek, i.e. a fast version of a mazurka. Both melodies belong to the few foreign written versions of Polish folklore which are unknown in Poland in the form presented by the composer. They are not even in the biggest collection of Polish folk songs (1865-1890) by O. Kolberg. Only variations (especially textual) are to be found in numerous later versions.

It is interesting to note how Beethoven's arrangements reflect all the typical styles characteristic of the playing of Polish folk music and folk dances. Beethoven's arrangements of these two songs also differ in their texture and harmonic characteristics from the more stereotyped and similar arrangements of folk songs of other nations, to be found in the same collection. Even further: the composer showed more sensitivity towards style here than in the other five Slavonic songs in the collection. 